\title{
Lost in translation? Accountability and governance of clinical stem cell research in China
}

\author{
Joy Y Zhang*,1 \\ ${ }^{1}$ School of Social Policy, Sociology \& Social Research, Cornwallis North East, University of Kent, Canterbury, Kent CT2 7NF, UK \\ * Author for correspondence: y.zhang-203@kent.ac.uk
}

\begin{abstract}
Despite China's regulatory initiatives to promote its research accountability, it still needs to prove itself as a trusted player in life science research. In addition, in contrast to its huge investment, China is losing the race in delivering quality application of stem cells. The trial implementation of the 2015 ministerial regulations seemed to offer hope in ending this dual 'lost-in-translation'. Yet skepticism remains. By examining China's regulatory trajectory in the last 15 years, this paper illustrates that it is a post hoc pragmatic policy rationale and a soft centralization regulatory approach that have hampered China's governance. To improve China's governance of accountability, policy-makers need to get beyond an 'act-in-response' regulatory ethos and to engage with diverse stakeholders.
\end{abstract}

First draft submitted: 15 March 2017; Accepted for publication: 7 July 2017; Published online: 4 October 2017

Keywords: accountability $\bullet$ centralization $\bullet$ China $\bullet$ enforcement $\bullet$ governance $\bullet$ policy $\bullet$ pragmatism $\bullet$ stem cell

In the last two decades, China has marched toward its stem cell ambition with big and bold strides. Being the world's second largest investor of stem cell research, the number of stem cell researchers in China has grown by 16-times since 2004, while the amount of academic publications has increased by 17-times [1]. In addition, rising clinical trials in China since 2008 have put Asia above North America and Europe in terms of numbers of experimental therapies [2]. Yet this huge investment of financial and human resources, along with sociopolitical encouragement, has not resulted in China's competitive advantage as a global leader in this field. Despite the fact that a number of companies in Europe, the USA, South Korea, Canada and Japan have received market approval for their stem cell-based products from their respective jurisdictions; in the eyes of Chinese researchers, the prospect for Chinese institutions to translate its laboratory findings into marketable stem cell-based products in the next 5 years remains dim [3]. In fact, the ill reputation of being the hotbed for unsupervised clinical trials has crippled China's translation of stem cell promises [4].

It was not until August 2015, when China's National Health and Family Planning Commission (NHFPC) and China's Food and Drug Administration (CFDA) jointly authorized the trial implementation of a set of long-waited regulations that the field of clinical stem cell research in China restored some order [5,6]. While this new set of policies has, at least domestically, introduced renewed optimism, a poor record of policy enforcement and a lack of regulatory clarity and consistency still loom over Chinese scientific practitioners and biomedical industry [7]. As one industrial scientist rightly argued in China Medical Biotechnology, with the promulgation of the 2015 regulations, China may be at the crossroads of becoming a leading player in world stem cells. If China gets its governance right, it could become a powerhouse for innovation. If the enforcement of the 2015 regulations turned sour, it could potentially create an insuperable 'Death Valley' between China's ambitions in the labs and their bedside applications [8].

Thus, the field of clinical stem cell research in China is confronting two interrelated 'lost-in-translations'. One is the failed translation of stem cell potential into reliable medical practices. The other is the failed translation of a permissive policy stance into a supportive research environment.

By systematically reviewing the development of China's stem cell regulations, this paper investigates the regulatory culture that gives rise to China's dual 'lost-in-translations'. I argue that it is a post hoc pragmatic policy rationale and 
a soft centralization regulatory approach that have damaged the effectiveness of China's stem cell governance. This is not to overlook the tremendous governance progress the Chinese government and Chinese scientific community have made in the last two decades. Rather the point is to identify possible impediments to the deliverance of accountable governance in China. For China to improve its research accountability, policy-makers need to get beyond a conventional 'act-in-response' regulatory ethos and construct a socially embedded regulatory system that engages with diverse stakeholders.

\section{Post hoc pragmatism \& its effects on accountable research}

The making of Chinese biomedical policies can be characterized as a practice of 'post hoc pragmatism' [9]. Here, the term 'pragmatism' denotes a reluctance to engage with wider social value debates and a consequent narrow focus on finding quick administrative fixes on identifiable problems and expressed concerns. Leading Chinese bioethicist Wang Yanguang described a common view that Chinese regulators in the health sector were dismissive in incorporating social debates into policy-making for 'however laudable the goals,' getting into the messiness of public views appears to be an 'inefficient' way to govern [10]. Policy-making for the life sciences, Wang argued, was oriented toward promoting the international stance of Chinese science [10]. Subsequently, Chinese biogovernance is often post hoc in the sense of being reactionary to international criticisms as opposed to being precautionary. The making of China's regulatory system of clinical stem cell research mirrors this policy orientation. As this section demonstrates, in comparison to many other countries, domestic concerns have played a relatively a small role in China's policy-making over stem cell research. The current regulatory framework is founded on a series of responses Chinese authorities have made toward international criticism [11,12]. The fact that Chinese stem cell policies have been largely steered by global perceptions rather than domestic concerns can be seen both in basic stem cell research (as shown in the 2003 example discussed below) and in related clinical studies (as shown in the 2009 example below). The pressure to address global scrutiny while preserving domestic creativity has led to a pragmatic search for regulatory patchworks, which may appear disruptive to research.

2003 arguably marked the beginning of China's national regulation on stem cell research, in which China's main research funder, the Ministry of Science and Technology, joined efforts with the then Ministry of Health $(\mathrm{MOH}$, predecessor of NHFPC) in promulgating the Ethical guidelines for research on human embryonic stem cells [13]. According to bioethicists who participated in the making of the guidelines, this was a government response to the 'Wild East' characterization that had been placed on China since Chen Xigu's 2001 creation of the world's first human-rabbit hybrid embryos in the absence of ethical review [9,14]. More importantly, the scope of this guideline was intentionally kept narrow so as to address immediate global concerns, rather than taking a more proactive steering of domestic research norms [15]. The resulting 2003 guidelines were mainly a repetition of existing western ethical principles with little procedural guidance on how it could be carried out. As such, domestically this guideline functioned 'more as educational material than an operational directive' [9].

In the years that followed, China gradually became a destination for desperate patients around the world to receive unproven and unregulated stem cell treatments $[4,16]$. Just as China was beginning to shrug off the 'Wild-East' notoriety, a new wave of global criticism arose over China's regulatory vacuum over stem cell therapies [17].

In response to growing skepticism, in May 2009, MOH promulgated the Regulations of Clinical Application of Medical Technology. These regulations in 2009 categorized stem cells as a high-risk 'Class III' medical technology, which is defined as 'having major ethical and safety concerns, with clinical efficacy yet to be tested' [17]. By listing stem cells as a Class III medical technology, the 2009 Regulations brought stem cell-related research under the direct supervision of the Ministry [17]. This was a key step to centralize the government's control over clinical stem cell research. Yet to some extent, similar to the 2003 guidelines, this policy response was more of a positional statement to appease international criticism than a practical solution to enhance domestic oversight. For example, following the publication of the 2009 regulations, in theory, institutions engaged with clinical research of stem cells were given until 31 October 2009 to file for ministerial approval if they wished to continue their respective research. In practice, the lack of procedural specificity and an absence of noncompliance penalties meant that for most practitioners, it was business as usual [17]. In fact, it was estimated that at least 200 hospitals in China continued to offer unproven therapies [18]. Chinese authorities had little influence over companies such as Belike Biotechnology, which claimed to supply stem cells to hospitals for treatment of a wide range of conditions $[18,19]$.

As criticism persisted, Chinese authorities resorted to a more drastic approach. That is, at the beginning of 2012, $\mathrm{MOH}$ halted all stem cell clinical research and clinical applications that were not approved by MOH and State Food and Drug Administration (SFDA, renamed as CFDA in 2013) and suspended ministerial review of new clinical 
stem cell research applications to July 2012 [20]. But 3 months after $\mathrm{MOH}$ announced its intention to clamp down on illegal practices, a Nature investigation found that 'businesses around the country are still charging patients thousands of dollars for these unproven therapies [21]. As the next section further elucidates, the failure of MOH's 2012 intervention was but one example of how relying on conventional top-down administrative commands alone significantly limited the steering of clinical stem cell research. A number of empirical studies rightly suggested that effective deterrence of stem cell tourism requires policy-makers to understand and to engage with diverse interests. In addition to the promotion of scientific transparency and public education, regulators need to channel rather than to simply negate stem cells' commercial appeal $[22,23]$. More importantly, only in this way can regulators perform a fine balancing act between irresponsible exploitation of desperate patients and innovative clinical practice [24].

To summarize, the first decade of China's attempt to govern research accountability was ineffective. Existing studies on China's stem cell regulations have identified factors such as a lack of procedural clarity, the fragmentation of regulatory responsibilities and ambiguities with noncompliance penalties, as impediments to good governance [2527]. Yet a post hoc pragmatic mindset may be a deeper reason to regulatory ineffectiveness.

There is nothing essentially wrong with being 'post hoc' (i.e., reactionary) or being 'pragmatic' (i.e., narrowly focused on addressing a particular criticism). But when a regulatory system is dominated by post hoc pragmatism, it reduces accountable governance to crisis management. It seems that Chinese regulators may have had wrongly equated permissive governance to parachuting in regulatory directives only when specific international concerns had been voiced [10]. Governance is then not so much founded on engaging with wider social values but on chasing after criticism. This seemingly pragmatic calculation arguably had turned the foundation and objectives of policies upside-down. A second consequence of a post hoc pragmatic orientation is that it curtailed regulatory consistency and coherency, which were crucial for scientific advancement.

China's 2013 circulation of a set of three draft regulations on stem cell clinical trials was seen as a turning point. It was China's first attempt to break away from relying on regulatory patchworks, to systematically introduce a set of regulatory tools to safeguard accountable research. This joint effort by $\mathrm{MOH}$ and the SFDA aimed to provide guidance both on the organization and conduct of clinical trials along with quality control standards [28-30]. These draft regulations clarified a few key issues. For example, they made an administrative distinction between approved stem cell treatments and stem cell clinical trials. Any form of marketization or fee-charging was prohibited for clinical trials. This distinction is important, as at the time, the Chinese government had officially recognized only one type of stem cell treatment, that is, the use of hematopoietic stem cells in hematological diseases (e.g., Leukemia). Thus, the 2013 draft regulations effectively brought all other clinical applications of stem cells under the umbrella of nonfee-charging practices. This was expected to reduce financial incentives for hospitals to recruit patients for approval-pending therapies. Furthermore, the draft regulations made an explicit requirement that clinical trials needed to be centrally registered, approved and annually reviewed by the MOH and SFDA. But similar to previous policies, these 2013 regulations were vague on the procedural details of how such approvals could be made and to whom. Consequently, while the 2013 regulations offered a glimmer of hope for a more orderly development of clinical stem cell research in China, it also effectively paralyzed many government funded projects and created frustrations among practitioners [31].

The 2013 draft formed the basis of current trial implementations of Management of Clinical Trial Research on Stem Cells and Guideline for Quality Control and Preclinical Studies of Stem cell Preparations promulgated in August 2015 [5,32]. Following these regulations, the newly formed NHFPC and CFDA were responsible to organize expert committees to certify, register and review clinical stem cell research in China [33]. This time, the 2015 regulations offered better procedural clarity on how approvals could be obtained. Thus, after a few years of waiting in suspense, Chinese principal investigators finally had some certainty over how to proceed with their research agenda [6]. The May 2016 announcement of the first 30 authorized institutions for stem cell research seemed to be an initial testimony to regulatory efficiency [34].

As Chinese authorities embarked on a more systematic approach to reform stem cell regulations, there seemed to be a reason for optimism. But Chinese regulators may still need to appreciate the value of having regulatory resilience and consistency. One example is that while the introduction of the 2015 regulations were widely welcomed by Chinese practitioners as signaling a 'new spring' to stem cell research, the death of 21-year-old college student Wei Zexi who was receiving experimental cell therapy at Beijing's Number Two Armed Policy Hospital in 2016 froze this field with an unexpected 'cold snap' [35]. The death of a terminally ill young man shocked the Chinese public for it was seen as an epitome of a number of social problems associated with healthcare, such as under-regulated medical advertisements, incomplete informed consent and a disregard to NHFPC's prohibition on fee-charging for 
experimental therapies [36]. With mounting media criticisms of Wei's death, NHFPC effectively made a blanket ban on clinical applications of cell immunotherapy, which was a large area of clinical stem cell research [35,37]. This decision seems to be reminiscent of how Chinese health authorities responded to the controversies on hybrid embryo research and on stem cell therapies. A disputable practice was pragmatically terminated to quiet social discussion in the short run. For the regulators, such pragmatism perhaps offers powerful and 'effective' answers to (political) accountabilities, but for scientific practitioners, its impact may be more disruptive than constructive.

Another weakness in China’s governance system which Wei Zexi's case exposed was that the hospital he received treatment from was a police hospital which was regulated by the military and fell outside of the jurisdictions of NHFPC. This further exposed the irony to NHFPC's supposed 'pragmatic' regulatory rationale, which was arguably far from 'practical' That is, NHFPC's blanket ban on cell immunotherapy not only wrongly penalized practitioners in civic laboratories and hospitals but it also failed to address the actual problem in Wei's case, that is, the jurisdiction divide between civil and military medical facilities. To complicate the regulatory landscape further, another reason for the lack of institutional oversight in Wei's case was because the military hospital outsourced its entire Tumor Biology Center to a private company. These layers of contractual relations are not rare in China's health system and have highlighted the tension between China's existing divisions of regulatory responsibilities and the evolving structures of biomedical practices. As is further discussed in the next section, this poses a new challenge to Chinese authorities to adapt its policy approach so as to cope with increasingly diversified research and application practices.

\section{Emerging blind spots in 'soft centralization'}

The previous section demonstrated that China's stem cell regulatory initiatives were often prompted by a 'pragmatic' search for a quick political response toward existing outcries. To clamp down on irresponsible research, the devising of policies has relied on what I termed a 'soft centralization' approach. Its meaning and effects are elucidated below in two steps.

First, centralized administrative authority and centralized control over access to national research resources were once seen by Chinese regulators as a crucial gatekeeper to keep the stem cell community within a manageable scope [9]. For example, China's clinical stem cell research once depended on a host institution's discretionary adaptation of international guidelines [38]. But through the succession of new regulatory moves in 2009, 2013 and 2015, as discussed in the previous section, the accreditation and annual reviews of stem cell clinical research centers are centralized to the authorities of two state agencies, NHFPC and CFDA [28,29]. More importantly, Chinese ministries-centralized control over the allocation of national funding and resources was considered as a de facto determinant on who are allowed into a certain research field [39]. According to the new 2015 regulations to qualify as site for stem cells trials, the prospect institution needs to be a 'Tier 3 Level A' hospital. The term 'Tier 3' signifies the concerned hospital is a Tertiary institution, which can deliver medical care, medical education and conduct medical research. Each Tier is further divided into three subsidiary levels to differentiate its capacity on basis of its size, service provisions and management and professional assessment. 'Level A' marks the highest rank. In addition, the regulations also required that prospect institutions to be part of national 'major research project' and had a competitive funding record [33]. In a country where state funding has been the main, and sometimes the only source for scientific development and where major grants are often 'commissioned' rather than awarded to selected individuals [39], it could be argued that these criteria have effectively limited the clinical research of stem cells to a relatively small circle of elite practitioners who are the beneficiaries of state sponsorship.

This instrumentalization of access to resources as a governing tool for research accountability is not new to China. One only needs to recall that after the promulgation of the 2003 Ethical Guidelines for Research on Human Embryonic Stem Cells, its vague terminology and a lack of operational details cast doubt on its actual impact [22]. To western critics, such guidelines were far from sufficient and China still suffered from an absence of 'clear national policies, with different institutions following different rules' [40]. However, in a correspondence published in Nature, a group of Chinese scientists rebuked such characterization, and defended that the 2003 guidelines were 'adequate, as nearly all scientific research in China rely/relied on government funding' [41]. Thus, at least in the eyes of institutional scientists, centralized funding was an effective governing leverage over what research could be done and under what conditions. For it used to be true that the field of stem cell research in China mainly (if not solely) consisted of practitioners associated with state-sponsored institutions.

However, as stem cell research continued to expand and develop over the last decade, centralized state funding started to lose its influence in restricting research communities in China. While it may still be true that government 
funding remains central to basic research, the marketization of experimental stem cell therapies and related stem cell products are increasingly independent of state support. In fact, despite the fact that China has yet to deliver and to approve a marketable stem cell-based product, private investments have already wagered on stem cell-related research. When the government announced its three draft regulations on clinical stem cell research in 2013, the prospect of five stem cell-related concept stocks rising in market value hits the news [42]. Similarly, after the promulgation of the 2015 regulations, China's domestic market was infused with excitement, with projections that stem cell-based regenerative medicine would reach 150 billion Chinese yuan ( US\$22 billion) in 2021 [43]. Currently, it is estimated that China has 200 companies engaged with stem cell-related research and innovations [37], which are itching to push forward stem cell trials as institutional scientists [44]. In addition, as is demonstrated by the Wei Zexi's case, the boundaries between private and public medical service providers are increasingly blurred by an entangled web of interests.

Thus, a question mark should be put on the assumed effectiveness of a centralized approach in China [39]. As the field of clinical stem cell research is increasingly crowded with myriads of private investments and commercial interests, simply denouncing practices outside of Tier 3 Level A hospitals as illegal, as the 2015 regulations did, may not be enough to either improve China's public accountability in clinical stem cell research or protect vulnerable patients. In late April 2017, just as the NHFPC and CFDA started to accept new clinical stem cell research accreditation applications from elite institutions, investigative reporters from the China Youth Daily exposed that the eligibility criteria used in the 2015 regulations simply forced hundreds of existing but not-yet-registered stem cell clinics, such as those based in Tier 3 Level B hospitals, to operate underground [45,46]. The root of this enforcement problem of the 2015 regulations, as succinctly pointed out by distinguished stem cell scientist Chaozhong Han, was that the old rationale of governing by limiting certain practices to a select few no longer reflected the actual scope of China's clinical stem cell research. In the words of Han, this centralization approach was "10 years too late" since patients' expectations, clinicians' ambitions and intense commercial interests have already taken off and cannot be simply dispelled by administrative orders [46]. Effective governance may require a more proactive engagement with diverse players in the field of stem cell research.

Second and relatedly, what further lessens the effectiveness of the centralization strategy is the fragmented nature of the Chinese political system. The enforcement of Chinese ministries' regulative schemes often hinges on varying degrees of commitments by different regional authorities and by other ministries with overlapping jurisdictions [47]. As briefly mentioned in the previous section, there are two parallel health authorities in China. Civil hospitals are under the jurisdictions of NHFPC, while military and armed police hospitals are subjected to the regulations of the China People's Liberation Army's General Logistics Department [20]. Regulations promulgated by civil authorities, such as the prohibition of hospitals' subcontracting its medical service to private providers, do not automatically apply to military hospitals. In addition, regional governments in China often have more autonomy than commonly assumed. It is not rare for local protection of economic interests to trump ministerial agendas [49]. Thus, China's stem cell policies to date are 'soft' regulations not least in the sense that they are not yet laws but also in the sense that their impacts are reduced by the negotiated implementation of regulators at different levels [7].

This further highlights the importance to collaborate and coordinate with diverse stakeholders and practitioners if national regulations were to have nationwide effects. In some cases, inattentiveness to research activities outside centralized funding schemes may create an adverse situation in which 'the bad drives out the good'. For example, during my fieldwork as Expert Consultant for the Ministry of Science commissioned project, 'Ethical Issues and Governing Strategies in Scientific Research' in 2014 [48], one stem cell scientist at Tongji University complained to us that as the then $\mathrm{MOH}$ had prohibited unauthorized stem cell research, his state-funded project was effectively suspended until further clarity from the government. In the meantime, rival researchers working in the commercial sector forged ahead, for their careers and future funding were independent from the state system. This is an illuminating anecdote on the 'soft' or limited-mandatory nature of China stem cell regulations and on how exiting centralized control falls short in acquiring full command of this field.

In short, China's stem cell research has largely been regulated through 'soft centralization'. That is, centralized control over national funding and administrative approval was once considered as an effective 'purifying' mechanism to contain research practices [41]. But as stem cell community continued to evolve, the pertinence of such an approach to the complex and entangled web of research should not be taken for granted. It may prematurely restrict the regulatory efficacy, and may also create a punitive impact on those who follow the rules. 


\section{Governing accountability \& accountable governance: a reflection}

Supporting stem cell research is strategic for China to establish leadership in global science. The last two 5-year plans for scientific development have identified clinical stem cell research as a special program under the Major National Scientific Research Plan [50]. But to translate this commitment into scientific impact, China still needs to prove itself as a 'trusted player in the competitive and skeptical global community of life scientists [51]. Unless China turns around its imprudent reputation in clinical stem cell research, it may fail to attract the best scientists and collaborators as well as constrain the progress of its application and marketization of stem cells [31,52].

To improve China's governance of accountability, in addition to exploring new ways to hold scientific practitioners and relevant stockholders (e.g., hospitals and companies) responsible for their conduct, regulatory bodies also need to be held accountable to the policies they set forth. More specifically, the delivery of effective governance may benefit from a reflection on what national regulations should take into account and for whom the policies should be held accountable to. This is where recognizing the roles post hoc pragmatism and soft centralization played in China's stem cell policies helps.

First, as rightly pointed out by Sleeboom-Faulkner [53], China's attitude toward science governance was oriented toward promoting 'innovation and development' rather than attending 'moral scruples'. In President Xi Jinping's 2016 address to the Chinese Academy of Sciences and Chinese Academy of Engineering, a dominance in stem cell science and its associated applications was described as a 'solid support' for socioeconomic development, and as emblematic of China becoming a global power [54]. China has been 'pragmatic' with stem cell regulations in the sense that, for the larger part of the past two decades, Chinese authorities have relied on regulatory patchworks to govern clinical stem cell research and have avoided embedding its policy-making in wider social value debates. Key regulatory steps were taken mainly in response to international skepticism. Arguably, this minimalist approach to stem cell policies may have allowed Chinese scientists to gain some head start in this field. But as this field started to mature and normalize globally, an absence of clear and justifiable regulatory support has often left Chinese stem cell research in a limbo. In addition, a 'pragmatic' fix to identifiable concerns has increasingly appeared to be disruptive rather than sensible. One only needs to be reminded of the scientific cost of what followed the hybrid embryo controversies more than a decade ago. Despite the fact that nonreproductive cloning is officially allowed in China, confronting with international skepticism over Chinese scientists' of the first hybrid embryo for research purpose, China effectively put a total ban on such research so as to silence criticism. This research was later picked up by the UK 7 years later, by which time Chinese research had lost the lead [9]. Similar interruptive decisions were also seen in the 2012 moratorium of stem cell clinical trials and recent ban on cell immunotherapy as discussed in previous sections. Thus to translate permissive regulatory intention into encouraging and supportive governance, a reframing of policy orientations may be necessary.

Second, a more proactive and socially embedded regulatory system also implies a step away from what policy researchers at the Chinese Academy of Sciences described as 'a linear understanding of innovation,' which leads to policies that fail to speak to the intricate web of interests and collaborations that are integral to contemporary science [55]. For China's governance over clinical stem cell research to be full-fledged, in addition to relying on centralized administrative control, it will need to confront the messiness of clinical reality and make more effort to engage with relevant authorities and diverse stakeholders.

\section{Conclusion}

To some extent, China appears to be a crippled giant in the world of clinical stem cell research. While it has the ambition and the resource to become a global leader in this field, China remains haunted by an 'image problem' created by the government's inability to whip increasingly diverse practices and interests into regulatory order and social credibility. By examining China's regulatory trajectory in the last 15 years, this paper illustrates that it is the post hoc pragmatic policy rationale and a soft centralization regulatory approach that have caused a 'lost in translation' of China's huge scientific potential.

More specifically, this paper points out that the reason Chinese regulators' 'pragmatic' approach to stem cell regulation often seems to be least practical was that the reluctance to inform policies with wider social debates has reduced government regulations to crisis management. While putting administrative restriction over the number of eligible players in clinical stem cell research domestically may appear to be a direct and effective way to restore order, this old 'centralization' rationale does not reflect the actual scope of current stem cell research in China nor does it address China's fragmented regulatory structure. Thus, for China's governance of research accountability to bear fruit, Chinese regulators need to first have a candid reflection on what constitutes accountable governance 
that is pertinent to the Chinese context. This includes the willingness to recognize expectations and concerns from diverse stakeholders. It also requires the determination to step out of the top-down approach and to work out a 'socially embedded' regulatory framework with various interest groups (e.g., patients, scientists, companies, local government and military authorities) from the bottom-up.

\section{Future perspective}

In the spring of 2017, China launched the world's first clinical trial in using human embryonic stem cells to treat Parkinson's disease [56] and founded a new 'cell factory' dedicated to the production of therapeutic stem cells for neurodegenerative disease in Guangzhou [57]. There is little doubt that in the next 5-10 years, China clinical stem cell research will continue to forge ahead. But for China to become a trusted powerhouse in global clinical stem cell research, a more transparent and structured governing framework that speaks to existing entangled web of interests is needed. This is perhaps a lesson Chinese regulators have only started to recognize.

Financial \& competing interests disclosure

The paper is based on the author's research activities funded by the Wellcome Trust and the Economic and Social Research Council in the UK. The author has acted as the Expert Consultant for China's Ministry of Science commissioned project, 'Ethical Issues and

\section{Executive summary}

- China's clinical stem cell research confronts two interrelated 'lost-in-translations':

- The failed translation of stem cell potential into reliable medical practices.

- The failed translation of a permissive policy stance into a supportive research environment.

Post hoc pragmatism \& its effects on accountable research

- The making of Chinese stem cell policies resembles a practice of 'post hoc pragmatism', which is oriented more toward seeking quick appeasement of criticisms than toward shaping research norms.

- The 2003 Ethical Guidelines for Research on Human Embryonic Stem Cells were promulgated in response to the 'Wild East' characterization, which resulted from China's creation of the world's first human-rabbit hybrid embryos.

- To address global concerns over stem cell tourism, the 2009 Regulations of Clinical Application of Medical Technology attempted to centralize the government's control over this field. But a lack of procedural consideration pertinent to the Chinese context rendered it little operability.

- The 2013 circulation of a set of three draft regulations on stem cell clinical trials was China's first attempt to systematically reform this field. The subsequent 2015 adoption of these draft regulations restored some order to this field. However, the Wei Zexi's case in 2016 exposed that post hoc pragmatism mentality remains.

Emerging blind spots in 'soft centralization'

- Centralized administrative authority and centralized control over access to national research resources were once considered as a crucial gatekeeper to keep the stem cell community within a manageable scope.

- The development of stem cell community challenges this centralization rationale, as the boundaries between private and public medical service providers are increasingly blurred by an entangled web of financial interests.

- In addition, the reality of jurisdiction divided between the civil and military medical facilities and between national and local governments curtails regulatory efficacy.

Governing accountability \& accountable governance: a reflection

- Safeguarding research accountability relies not on one-sided instruction but depends on mutual commitments from the regulator and the regulated. In addition to exploring new ways to hold practitioners responsible for their conduct, regulatory bodies also need to be held accountable to the policies they set forth.

- Accountable governance also requires a step away from a linear understanding of innovation and recognizes the intricate web of interests and collaborations that are integral to contemporary science.

Conclusion

- The reason Chinese regulators' 'pragmatic' approach to stem cell regulation often seems to be least practical was that the reluctance to inform policies with wider social debate has reduced government regulations to crisis management.

- While putting administrative restriction over the number of eligible players in clinical stem cell research may appear to be an effective way to restore order, this old 'centralization' rationale does not reflect the actual scope of stem cell research in China nor does it address China's fragmented regulatory structure.

Future perspective

- The prospect of China becoming a trusted powerhouse in clinical stem cell research hinges on Chinese regulators' willingness to work out a 'socially embedded' regulatory framework with diverse stakeholders from the bottom-up. 
Governing Strategies in Scientific Research' in 2014, but no payment was received and the fieldwork was self-funded. The author has no other relevant affiliations or financial involvement with any organization or entity with a financial interest in or financial conflict with the subject matter or materials discussed in the manuscript apart from those disclosed.

No writing assistance was utilized in the production of this manuscript.

\section{Open access}

This work is licensed under the Attribution-NonCommercial-NoDerivatives 4.0 Unported License. To view a copy of this license, visit http://creativecommons.org/licenses/by-nc-nd/4.0/

\section{References}

Papers of special note have been highlighted as: $\bullet$ of interest; $\bullet \bullet$ of considerable interest

1 People's Daily. Exploring stem cell technology: stem cell therapy when will dream come true? (2015). http://news.xinhuanet.com/tech/2015--02/02/c_127447309.htm

2 Li MD, Atkins H, Bubela T. The global landscape of stem cell clinical trials. Regen. Med. 9(1), 27-39 (2014).

3 Wu SX, Yang SJ, Wu ZZ. Study on the regulation of cell therapies in the US, the EU and Japan. Chin. Med. Biotechnol. 11(6), 491-496 (2016).

4 Wahlberg A, Streitfellner T. Stem cell tourism: desperation and the governing of new therapies'. In: Life Sciences in Translation. A Sino-European Dialogue on Ethical Governance of the Life Sciences. Doering O (Ed.). BIONET, London, UK, 81-97 (2009).

5 National Health and Family Planning Commission, China’s Food and Drug Administration. Management of clinical trial research on stem cells (for trial implementation) (2015). www.sda.gov.cn/WS01/CL0053/127243.html

6 Cyranoski D. China announces stem-cell rules. Nature (2015). www.nature.com/news/china-announces-stem-cell-rules- 1.18252

7 Roseman A, Sleeboom-Faulkner M. New regulation for clinical stem cell research in China: expected impact and challenges for implementation. Regen. Med. 11(1), 5-9 (2016).

-. Detailed review of the 2015 regulations.

8 Zhang L. How stem cell innovation can cross the 'death valley'. Chin. Med. Biotechnol. 10(5), 385-391 (2015).

9 Zhang JY. The Cosmopolitanization of Science: Stem Cell Governance in China. Palgrave Macmillan, Basingstoke, UK (2012).

-• Key empirical work on how China's stem cell governance was organized and developed.

10 Wang YG. A strategy of clinical tolerance for the prevention of HIV and AIDS in China. J. Med. Philos. 25(1), 48-61 (2000).

11 Doering $\mathrm{O}$. Chinese researchers promote biomedical regulations: what are the motives of the biopolitical dawn in China and where are they heading? Kennedy Inst. Ethics J. 14(1), 39-46 (2004).

12 Salter B, Qiu RZ. Bioethical governance and basic stem cell science: China and the global biomedicine economy. Sci. Public Policy 36(1), $1-13$ (2009).

13 Ministry of Science and Technology (China). Ethical guidelines for research on human embryonic stem cells (2003). www.most.gov.cn/fggw/zfwj/zfwj2003/200512/t20051214_54948.htm

14 Dennis C. China: stem cells rise in the east. Nature 419, 334-336 (2002).

15 Xiao XJ. The absence of 'ethics' in 'ethical guidelines'. Scientific Times (Kexue Shibao), 23 July (2004).

16 Liao LM, Zhao CHR. An overview of stem cell-based clinical trials in China. Stem Cells Dev. 17(4), 613-618 (2008).

17 Ministry of Health (China). Regulations of clinical application of medical technology (2009). www.moh.gov.cn/mohyzs/s3585/200903/39511.shtml

18 McMahon DS, Thorsteinsdóttir H, Singer PA, Daar AS. Cultivating regenerative medicine innovation in China. Regen. Med. 5, 35-44 (2010).

- Empirical study on how diverse groups are active in the field of experimental stem cell therapies in China.

19 Economist. Wild East or scientific feast? (2010). www.economist.com/node/15268869

20 State Food and Drug Administration (China). Notification on self-scrutiny and self-correction on stem cell clinical research and applications (2012). www.sda.gov.cn/WS01/CL0844/68315.html

21 Cyranoski D. China’s stem cell rules go unheeded. Nature 484(7393), 149-150 (2012).

22 Einsiedel EF, Adamson H. Stem cell tourism and future stem cell tourists: policy and ethical implications. Dev. World. Bioeth. 12(1), 35-44 (2012).

23 Master Z, Resnik DB. Stem-cell tourism and scientific responsibility. Stem-cell researchers are in a unique position to curb the problem of stem-cell tourism. EMBO Rep. 12(10), 992-995 (2011)

24 Lindvall O, Hyun I. Medical innovation versus stem cell tourism. Science 324, 1664-1665 (2009). 
25 Qiu RZ. Comments on the "ethical guidelines for research on human embryonic stem cells". Medicine and Philosophy (Yixue yu Zhexue) 25, 1 (2004).

26 Zhang JY. The organization of scientists and its relation to scientific productivity: perceptions of Chinese stem cell researchers. Biosocieties. 5(2), 219-235 (2010).

Resnik D, Zeng W. Research integrity in China: problems and prospects. Dev. World Bioeth. 10, 164-171 (2010).

28 Ministry of Health, State Food and Drug Administration (China). Managerial rules on the research base for stem cell clinical trials (draft) (2013). www.moh.gov.cn/wsb/pzcjd/201303/c378874464f348ea876466d8b8812338.shtml

29 Ministry of Health, State Food and Drug Administration (China). Managerial rules on stem cell clinical trials research (draft) (2013). www.moh.gov.cn/wsb/pzcjd/201303/022ce8030a36442bab563d07c57faf1b.shtml

30 Ministry of Health, State Food and Drug Administration (China). Guideline for quality control and preclinical studies of stem cell preparations (Draft) (2013). www.moh.gov.cn/wsb/pzcjd/201303/70f7dd3e1e5d4090a0cfcee6ba6291e2.shtml

31 Shao P (Ed.). Interview with Xu Guotong: our stem cell clinical research is relatively behind. Sohu (2014). http://health.sohu.com/20140825/n403748671.shtml

32 National Health and Family Planning Commission. China’s Food and Drug Administration. Guideline for quality control and preclinical studies of stem cell preparations (2015). www.moh.gov.cn/qjjys/s3581/201508/15d0dcf66b734f338c31f67477136cef.shtml

33 National Health and Family Planning Commission, China’s Food and Drug Administration. Notification on the registration of clinical stem cell research institutions (2015). www.nhfpc.gov.cn/qjjys/s3581/201512/a8ef28444b8e4d4382f06353bb09909c.shtml

34 National Health and Family Planning Commission. Public announcement of the first patch of stem cell clinical research institutions (2016). www.nhfpc.gov.cn/qjiys/s7946/201610/5cf9395f07424745be940ee2bcff3d61.shtml

35 Jourdan A. False hope? China's military hospitals offer illegal experimental cures. Reuters (2016). www.reuters.com/article/us-china-hospitals-insight-idUSKCN0ZR0BW

36 Chuan J. The Wei Zexi Case: who is supervising the people's military hospitals. BBC (2016). www.bbc.com/zhongwen/simp/china/2016/05/160504_china_military_hostpital_scandal

37 Liu T. The Wei Zexi Case and its impact on the 10-billion cell therapy industry. Sina (2016). http://finance.sina.com.cn/chanjing/cyxw/2016--05--06/doc-ifxryhhh1708034.shtml

38 Rosemann A. Standardization as situation-specific achievement: regulatory diversity and the production of value in intercontinental collaborations in stem cell medicine. Soc. Sci. Med. 122, 72-80 (2014).

- Illuminates how China balances global trend and local norm in regulating regenerative stem cell medicine.

39 Zhang JY. Does China offer a new paradigm for doing science? In: China's Many Dreams: Comparative Perspectives on China's Search for National Rejuvenation. Kerr D (Ed.). Palgrave Macmillan, Basingstoke, UK, 156 -179 (2014).

40 Giles J. Rules tighten for stem-cell studies. Nature 440, 9 (2006).

41 Cheng L, Qui R, Deng H, Zhang YA, Jin Y, Li L. Ethics: China already has clear stem-cell guidelines. Nature 440, 992 (2006).

- Chinese scientists' view on effective stem cell governance in an authoritarian state.

42 Chen H. Stem cell concept stock optimist on policy breakthrough. Chinese Securities J. (2014). http://finance.sina.com.cn/stock/hyyj/20141225/105021162874.shtml

43 China Regenerative Medicine Institute. China’s stem cell market is to reach 150 billion in five years time! (2016). www.akbiomedical.com/news_detail/newsId=49.html

44 Zhong H, An XY, Dan LH, Li HC, Huang JX, Chi H. A review of the development of China’s stem cell industry. Chin. Med. Biotechnol. 7(1), 2-4 (2012).

45 National Health and Family Planning Commission, China’s Food and Drug Administration. Notice on enhancing the registration and supervision of stem cell clinical research (2017). www.nhfpc.gov.cn/qjjys/s3581/201704/a575a03b6a774eeda93527753ad6cc0c.shtml Lu YJ, Zhang MR, He XY. Exposing the undercurrent of cell therapy. China Youth Daily (2017). www.chinanews.com/jk/2017/04--26/8209047.shtml

47 Zhang JY. Scientific institutions and effective governance: a case study of Chinese stem cell research. New Genet. Soc. 30(2), 193-207 (2011).

48 Zhang JY. The 'credibility paradox' in China's science communication: views from scientific practitioners. Public Underst. Sci. 24(8), 913-927 (2015).

49 Lieberthal KG, Lampton DM. Bureaucracy, Politics, and Decision Making in Post-Mao China. University of California Press, CA, USA (1992).

50 Minister of Science and Technology (China). The national twelfth five-year plan on science and technology development. (2012). www.most.gov.cn/kjgh/

51 Moreno J. Will China achieve science supremacy? The stem cell example. NY Times (2010).

http://roomfordebate.blogs.nytimes.com/2010/01/18/will-china-achieve-science-supremacy/?_r=0 
52 Levine AD. Science policy and the geographic preference of stem cell scientists: understanding the appeal of China and Singapore. New Genet. Soc. 29(2), 187-208 (2010).

53 Sleeboom-Faulkner ME. National risk signatures and human embryonic stem cell research in mainland China. Health Risk Soc. 12(5), 491-511 (2010).

- Provides insights on how Chinese regulators orient research ethics in stem cell research.

54 Xinhua Press. Xi Jiping delivered important speech at the 17th Academician Conference of CAS and the 12th Academician Conference of CES. (2016). http://news.xinhuanet.com/politics/2014--06/09/c_126597413.htm

55 Gu S, Landfall B, Liu J, Malaria F, Serger SS. China’s system and vision of innovation: an analysis in relation to the strategic adjustment and the medium- to long-term S\&T development plan (2006-2020). Industry \& Innovation 16(4), 369-388 (2009).

56 Wang P, Li X. Key breakthrough in China’s stem cell research, threshold remains for clinical application. Economic Information Daily (China) (2015). http://news.china.com.cn/2017--05/26/content_40897951.htm

57 Cryanoski D. Trials of embryonic stem cells to launch in China. Nature 546, 15-16 (2007). 